E. A. Dolmatova, A. V. Patrushev, T. N. Ostanina

Ural Federal University,

620002, Ekaterinburg, 19, Mira St, Russia.

Tel.: (343) 375- 44-63;

E-mail:arcfan@yandex.ru

\title{
Measurement of the specific surface area of loose copper deposit by electrochemical methods
}

In the work the surface area of the electrode with dispersed copper deposit obtained within 30 seconds was evaluated by techniques of chronopotentiometry (CPM) and impedance spectroscopy. In method CPM the electrode surface available for measurement depends on the value of the polarizing current. At high currents during the transition time there is a change of surface relief that can not determine the full surface of loose deposit. The electrochemical impedance method is devoid of this shortcoming since the measurements are carried out in indifferent electrolyte in the absence of current. The area measured by the impedance is tens of times higher than the value obtained by chronopotentiometry. It is found that from a solution containing sulfuric acid the deposits form with a high specific surface area. Based on these data it was concluded that the method of impedance spectroscopy can be used to measure in situ the surface area of the dispersed copper deposits.

Key words: current, chronopotentiometry, loose copper deposit, depletion factor, impedance spectroscopy.

Е. А. Долматова, А. В. Патрушев, Т. Н. Останина

\section{Измерение удельной поверхности рыхлого осадка меди электрохимическими методами}

В работе проведена оценка площади поверхности электрода с дисперсным осадком меди, полученным в течение 30 секунд методами хронопотенциометрии (ХПМ) и импедансной спектроскопии. В методе ХПМ поверхность электрода, доступная для измерения, зависит от величины поляризующего тока. При больших токах в течение переходного времени происходит изменение рельефа поверхности, что не позволяет определить полную поверхность рыхлого осадка. Метод электрохимического импеданса лишен этого недостатка, так как измерения проводятся в индифферентном электролите в отсутствие тока. Площадь, измеренная методом импеданса, в десятки раз превышает значения, полученные методом хронопотенциометрии. Установлено, что из раствора, содержащего серную кислоту, формируются осадки с высокой удельной поверхностью. На основании полученных данных сделан вывод, что метод импедансной спектроскопии может быть использован для измерения in situ площади поверхности дисперсных осадков меди.

Ключевые слова: ток; хронопотенциометрия; осадок свободной меди; коэффициент истощения; импедансная спектроскопия.

(c) Dolmatova E. A., Patrushev A. V., Ostanina T. N., 2016 


\section{Introduction}

Copper powder is widely used in powder metallurgy, mechanical engineering, aviation, chemistry, electrical engineering industry. The production of copper powders was based on a process of electroreduction of copper ions from aqueous solutions at currents exceeding the limiting diffusive current. A feature of the process is the joint discharge of metal ions and hydrogen. The hydrogen evolution occurs so rapidly that the hydrogen absorption causes the "navodorazhivanie» of copper surface, affecting on deposit properties. The bubbles of gas shake the electrolyte in

\section{The experimental part}

To study the reduction process of copper ions the electrolytes were used:

$1-0.12 \mathrm{~mol} / \mathrm{l} \mathrm{CuSO}_{4}+1 \mathrm{~mol} / \mathrm{l} \mathrm{H}_{2} \mathrm{SO}_{4}$

$2-0.12 \mathrm{~mol} / 1 \mathrm{CuSO}_{4}+1 \mathrm{~mol} / 1 \mathrm{Na}_{2} \mathrm{SO}_{4}$.

Polarization measurements were carried out using an electrochemical test system AutolabPGstat 302N. The working electrode is a copper pin $1.5 \mathrm{~mm}$ in diameter with a working surface area $S=$ $0.471 \mathrm{~cm}^{2}$. The counter electrode is made of copper foil. The potential was measured relative to unpolarized copper electrode in a suitable solution.

The dendritic copper deposits were obtained under galvanostatic conditions if the setting current (I) exceeds the value of the limiting diffusion current on the smooth surface of electrode (Id) to $K_{i}=$ 6 times. The concept of the depletion factor was introduced by A.V. Pomosov [1] to determine the depth of the diffusion limitation of the discharge process of metal. The deposit was obtained within 30 seconds to development of the surface was not very large. During electrolysis the amount of evolved hydrogen was meas- the electrode space, thus affecting the parameters of the electrode reaction.

The study of the electrode processes mechanism at high current densities is of particular interest However to solve this problem it is necessary to know the electrode surface area with disperse deposit on which electrochemical processes take place.

The aim of this study was the choice of the electrochemical method of determination in situ of electrode surface area with dispersed copper deposit.

ured for this burette with a funnel on the end was set above the electrode.

To determine the electrode surface area with a loose deposit $\left(S_{d e p}\right)$ chronopotentiometry method at a constant current was used [2]. Previously on the smooth electrode chronopotentiograms series at different currents were shooting (Fig. 1) and a transition time $(\tau)$ was defined on them. In the investigated solutions the dependence of the current density (i) has a linear character [3]:

$$
i \sqrt{\tau}=A-B \cdot i \text {, }
$$

where $\mathrm{A}$ and $\mathrm{B}$ are empirical constants whose values are determined by the analysis of experimental data (Tabl. 1).

Table 1

The coefficients $A$ and $B$ values

\begin{tabular}{l|c|c} 
& Solution 1 & Solution 2 \\
\hline $\mathrm{A}, \mathrm{A} \cdot \mathrm{s}^{1 / 2} / \mathrm{m}^{2}$ & 637.711 & 466.6 \\
\hline $\mathrm{B}, \mathrm{s}^{1 / 2}$ & 0.369 & 0.168
\end{tabular}

After electrolysis the electrode with the dispersed deposit was kept in the solution for 10 minutes to restore concentration of the copper ions at the electrode 
surface. Then chronopotentiogram take off and the area of the electrode with the precipitate $S_{d e p}$ [2] is determined on transition time value taking into account the constants $\mathrm{A}$ and $\mathrm{B}$ :

$$
S_{d e p}=\frac{I(\sqrt{\tau}+B)}{A} .
$$

When determining the surface area of the electrode with the deposit by impedance spectroscopy the measurements were carried out in a solution of $0.5 \mathrm{~mol} / \mathrm{l}$ $\mathrm{Na}_{2} \mathrm{SO}_{4}$ with the aid of electrochemical station Zahner IM6 in the frequency range from $1 \mathrm{~Hz}$ to $500 \mathrm{kHz}$. As the reference electrode a saturated silver chloride electrode was used, the counter electrode was a platinum plate. Impedance spectra were recorded on a smooth electrode and on the electrode with loose deposit.

Experimental impedance hodographs were approximated using the equivalent circuit (Fig. 2), which Canadian scientists previously proposed [4] to simulate the behavior of porous electrodes.

When analyzing of the electrode impedance with a loose deposit the circuit elements had the following physical meaning: $R_{1}$ is the solution resistance in the cell; $\mathrm{C}$ is the capacity of the electrical double layer at the front of deposit growth; resistance $\mathrm{R}_{2}$ and constant phase element CPE are resistance and distributed capacitance within the layer of loose deposit. The schema options were selected using EC-Lab.

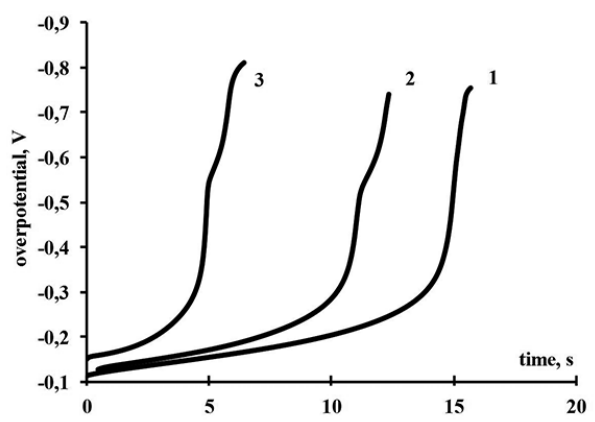

Fig. 1. Chronopotentiograms obtained on a smooth electrode in solution 1 at different currents.

The current values, A: $1-0.01 ; 2-0,012$;

$$
3-0.017
$$

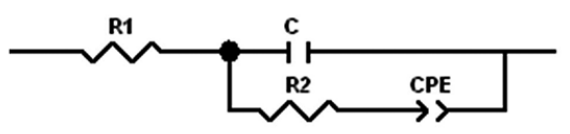

Fig. 2. The equivalent circuit of the electrode impedance with a loose deposit

Using the values of parameters of the equivalent circuit was calculated capacitance of the double layer of smooth electrode $\bar{C}_{s m}$ and the electrode with the deposit $\bar{C}_{d e p}$. From the value $\bar{C}_{s m}$ the specific capacitance $C_{\text {sp }}$ was measured considering the surface area of a smooth electrode $S_{s m}$ [2]:

$$
C_{s p}=\frac{C_{s m}}{S_{s m}} .
$$

The surface area of loose deposit (Sdep) was determined as the ratio of the electrode capacity with deposit to the specific capacity of the electrical double layer:

$$
S_{d e p}=\frac{\bar{C}_{d e p}}{C_{s p}} .
$$

\section{Results of the experiments}

1. Determination of the electrode surface area with the disperse deposit by chronopotentiometry method
Loose copper deposit is a complex structure consisting of a large number of branched dendritic particles. To deter- 
mine the electrode surface area with the deposit chronopotentiograms were recorded at different currents. At the same time with an increase in current the measured surface area increased (Fig. 3). This fact can be explained by fractal properties of dispersed deposit: the thickness of diffusion layer is reduced with growth of the current and all finer details of the surface relief of loose electrode are available for the measurement. The dependence of the electrode surface area with the deposit from the current value was observed in both the investigated solutions. At high currents the transition time was not possible to measure due to changes of surface deposit in the process of record of chronopotentiograms.

To quantify the deposit dispersion the coefficient of the surface development $k=$ $=S_{\text {dep }} / S$ ( $S$ is smooth electrode surface area) was calculated (Table 2). It is found that within 30 seconds of electrolysis the surface area of loose copper deposit in solution 1 with sulfuric acid is higher than in solution 2 with sodium sulfate.

Values $S_{\text {dep }}$ and k measured at high currents are shown in Tabl. 2. These re-

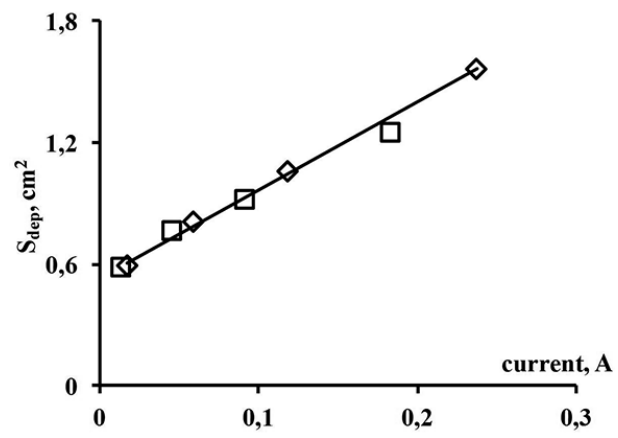

Fig. 3. Current influence on the surface area of a disperse copper deposit measured by chronopotentiometry method.

Deposits of copper obtained by $\mathrm{K}_{\mathrm{i}}=6$ from solutions $1(\diamond)$ and $2(\square)$ sults indicate the surface development during copper deposit growth. However the dependence of results on the current magnitude in the measurements shows the impossibility of measuring of the entire electrode surface with a loose deposit using the method chronopotentiometry.

Table 2

The values of the copper deposits surface area measured by chronopotentiometry method

\begin{tabular}{l|c|c}
\multirow{2}{*}{ Parameter } & \multicolumn{2}{|c}{ Solutions } \\
\cline { 2 - 3 } & Solution 1 & Solution 2 \\
\hline$S_{\text {dep }} \cdot 10^{4}, \mathrm{~m}^{2}$ & 1.56 & 1.25 \\
\hline$k$ & 3.32 & 2.65
\end{tabular}

2. Determination of the electrode surface area with the disperse deposit by impedance spectroscopy method

Comparison of experimental and calculated impedance spectra (Fig. 4) shows a good approximation.

The results of calculating the value of surface area on the equations 3-4 are presented in Tabl. 3.

The area disperse deposit measured by impedance is higher in ten times than the value obtained by chronopotentiometry (Tabl. 2).

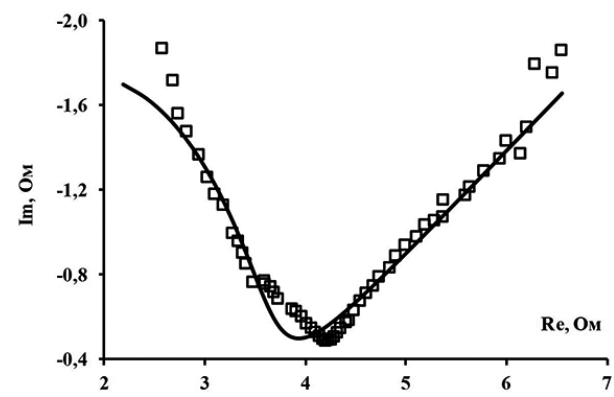

Fig. 4. The impedance spectrum of copper deposit obtained in solution 1. Markers are experimental data, line is approximation according to the accepted the equivalent circuit 
From a practical point of view such characteristic as specific surface is a very important $S_{s p}=S_{d e p} / m_{d e} p$.

The values of the copper deposits surface area measured by by impedance

\begin{tabular}{l|c|c}
\multirow{2}{*}{\multicolumn{2}{c}{ Parameter }} & \multicolumn{2}{c}{ Solutions } \\
\cline { 2 - 3 } & Solution 1 & Solution 2 \\
\hline$S_{\text {dep }} \cdot 10^{4}, \mathrm{~m}^{2}$ & 20.825 & 6.348 \\
\hline$k$ & 44.214 & 13.478 \\
\hline Current efficiency & 0.78 & 0.23 \\
\hline $\mathrm{m} \cdot 10^{4}, \mathrm{~g}$ & 2.73 & 0.62 \\
\hline$S_{s p}, \mathrm{~m}^{2} / \mathrm{g}$ & 5.921 & 2.337
\end{tabular}

The weight of the deposit was determined by Faraday's law:

$$
m_{d e p}=\frac{A_{C u}}{z F} I \cdot t \cdot C e_{C u},
$$

where $A_{C u}$ is atomic weight of copper, $t$ is time of electrolysis, $I$ is current; $C e_{C u}$ is current efficiency of copper.

In the obtaining of copper disperse deposit on the electrode the reactions of reduction of the metal and hydrogen si- multaneously take place. By the volume of evolved gas in the electrolysis process the current efficiency of hydrogen was determined and then the current efficiency of copper was calculated:

$$
C e_{C u}=1-\frac{V_{s c}^{H_{2}} \cdot F}{\vartheta_{g} \cdot I \cdot t},
$$

where $V_{s c} \mathrm{H}_{2}$ is the hydrogen volume, brought to standard conditions, $\vartheta_{g}$ is molar volume of gas.

The conducted research has shown that when using a solution containing sulfuric acid the copper disperse deposits with high surface area form (Tabl. 3). When electrodeposition from a solution with sodium sulfate less branched particles form as evidenced by the significantly lower surface area of the deposit and by low specific surface.

Based on these results we can conclude that the method of impedance spectroscopy allows to measure the surface area of the copper disperse deposit in situ with a high degree of reliability.

\section{In russian}

\section{Введение}

Медный порошок достаточно широко применяют в порошковой металлургии, машиностроении, авиации, химии, электротехнической промышленности. Получение медных порошков основано на процессе электровосстановления ионов меди из водных растворов при токах, превышающих предельный диффузионный. Особенностью процесса является совместный разряд ионов металла и водорода. Выделение водорода происходит настолько интенсивно, что вызывает наводо- раживание поверхности меди, влияя на свойства осадка. Его пузырьки перемешивают электролит в приэлектродном пространстве, тем самым воздействуя на ход электродной реакции.

Особый интерес представляет исследование механизма электродных процессов в условиях высоких плотностей тока. Однако для решения этой задачи необходимо знать площадь поверхности электрода с дисперсным осадком, на которой протекают электрохимические процессы. 
Цель настоящей работы состояла в выборе электрохимического метода определения in situ площади поверхно- сти электрода с дисперсным осадком меди.

\section{Методика эксперимента}

Для исследования процесса восстановления ионов меди были использованы электролиты:

1 - 0,12 моль/л $\mathrm{CuSO}_{4}+1$ моль/л $\mathrm{H}_{2} \mathrm{SO}_{4}$.

2 - 0,12 моль/л $\mathrm{CuSO}_{4}+1$ моль/л $\mathrm{Na}_{2} \mathrm{SO}_{4}$.

Поляризационные измерения проводили с помощью электрохимической станции AutolabPGstat 302N. В качестве рабочего электрода использовали штырьковый электрод из меди диаметром 1,5 мм с площадью рабочей поверхности $S=0,471 \mathrm{~cm}^{2}$. Вспомогательный электрод был изготовлен из медной фольги. Потенциал измеряли относительно неполяризованного медного электрода в соответствующем растворе.

Дендритные осадки меди получали в гальваностатических условиях при задании тока (I), превышающего величину предельного диффузионного тока на гладкой поверхности электрода $\left(\mathrm{I}_{\mathrm{d}}\right)$ в $\mathrm{K}_{\mathrm{u}}=6$ раз. Понятие коэффициента истощения $\mathrm{K}_{\mathrm{u}}=\mathrm{I} / \mathrm{I}_{\mathrm{d}}$ было введено А. В. Помосовым [1] для определения глубины диффузионных ограничений процесса разряда металла. Осадок получали в течение 30 с, чтобы развитие поверхности было не очень большим. В процессе электролиза измеряли объем выделяющегося водорода, для чего над электродом устанавливали бюретку с воронкой на конце.

Для определения площади поверхности электрода с рыхлым осадком $\left(S_{\text {ос }}\right)$ использовали метод хронопотен- циометрии при постоянном токе [2]. Предварительно на гладком электроде снимали серию хронопотенциограмм при разных токах (рис. 1) и определяли по ним переходное время ( $\tau)$. В исследованных растворах зависимость от плотности тока $(i)$ имела линейный характер [3]:

$$
i \sqrt{\tau}=A-B \cdot i,
$$

где $A$ и $B$ - эмпирические константы, значения которых определяли в ходе анализа экспериментальных данных (табл. 1).

Таблица 1

Значения коэффициентов А и В

\begin{tabular}{c|c|c} 
Коэффициент & Раствор 1 & Раствор 2 \\
\hline $\mathrm{A}, \mathrm{A} \cdot \mathrm{c}^{1 / 2} / \mathrm{M}^{2}$ & 637,711 & 466,6 \\
\hline $\mathrm{B}, \mathrm{c}^{1 / 2}$ & 0,369 & 0,168
\end{tabular}

После электролиза электрод с дисперсным осадком выдерживали в растворе в течение 10 мин. для восстановления концентрации ионов меди у поверхности электрода. Затем сни-

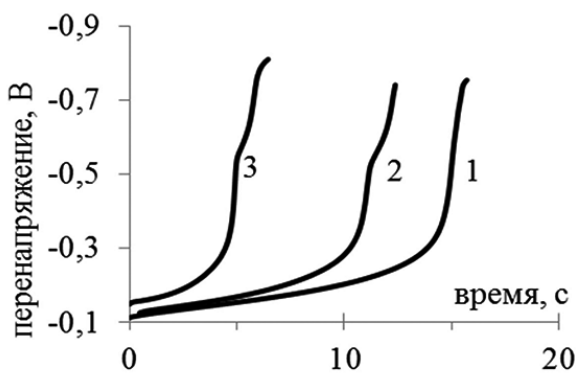

Рис. 1. Хронопотенциограммы, полученные на гладком электроде в растворе 1 при разных токах. Величина тока, А: 1 - 0,01; 2 - 0,012;

$$
3-0,017
$$


мали хронопотенциограмму и по величине переходного времени с учетом констант $A$ и $B$ определяли площадь электрода с осадком $S_{\text {ос }}$ [2]:

$$
S_{\mathrm{oc}}=\frac{I(\sqrt{\tau}+B)}{A} .
$$

При определении площади поверхности электрода с осадком методом импедансной спектроскопии измерения проводили в растворе 0,5 моль/л $\mathrm{Na}_{2} \mathrm{SO}_{4}$ с помощью электрохимической станции Zahner IM6 в диапазоне частот от 1 Гц до 500 кГц. В качестве электрода сравнения использовали насыщенный хлоридсеребряный электрод, вспомогательным электродом служила платиновая пластина. Спектры импедансов снимали на гладком электроде и на электроде с рыхлым осадком.

Экспериментальные годографы импеданса аппроксимировали с помощью эквивалентной схемы (рис. 2), предложенной ранее канадскими учеными [4] для моделирования поведения пористых электродов.

При анализе импеданса электрода с рыхлым осадком элементы схемы имели следующий физический смысл: $R_{1}$ - сопротивление раствора в ячейке; $C$ - емкость двойного электрического

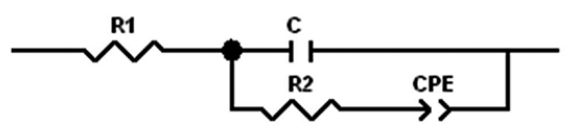

Рис. 2. Эквивалентная схема импеданса электрода с рыхлым осадком электрода

слоя на фронте роста осадка; сопротивление $R_{2}$ и элемент постоянной фазы $C P E$ - сопротивление и распределенная емкость внутри слоя рыхлого осадка. Параметры схемы подбирали с помощью программы EC-Lab.

Используя значения параметров эквивалентной схемы, рассчитывали емкость двойного слоя гладкого электрода $\bar{C}_{\text {гл }}$ и электрода с осадком $\bar{C}_{\text {дэс. }}$.о величине $\bar{C}_{\text {гл }}$ с учетом площади гладкого электрода $S_{\text {гл }}$ определяли удельную емкость $C_{\text {уд }}[2]$ :

$$
C_{\text {уд }}=\frac{C_{\text {гл }}}{S_{\text {гл }}},
$$

Площадь поверхности рыхлого осадка $\left(S_{\text {ос }}\right)$ определяли как отношение емкости электрода с осадком к удельной емкости двойного электрического слоя:

$$
S_{\text {ос }}=\frac{\bar{C}_{\text {дэС }}}{\mathrm{C}_{\text {уд }}} .
$$

\section{Результаты экспериментов}

1. Определение пломади поверхности электрода с дисперсным осадком методом хронопотенииометрии

Рыхлый осадок меди представляет собой сложную структуру, состоящую из большого количества разветвленных дендритных частиц. Для определения площади поверхности электрода с осадком хронопотенциограммы снимали при разных токах. При этом с увеличением тока измеренная площадь поверхности возрастала (рис. 3). Данный факт можно объяснить фрактальными свойствами дисперсного осадка: по мере роста тока уменьшается толщина диффузионного слоя и все более мелкие детали рельефа поверхности рыхлого электрода становятся доступными для измерения. Зависимость площади поверхности электрода 
с осадком от величины тока наблюдали в обоих исследованных растворах. При больших токах измерить переходное время не удавалось из-за изменения поверхности осадка в процессе съема хронопотенциограммы.

Для количественной оценки дисперсности осадка рассчитывали коэффициент развития поверхности $k=$ $=S_{\text {ос }} / S(S-$ площадь поверхности гладкого электрода) (табл. 2). Установлено, что за 30 с электролиза площадь поверхности рыхлого осадка меди в растворе 1 с серной кислотой выше, чем в растворе 2 с сульфатом натрия.

Значения площади поверхности осадков меди, измеренные методом хронопотенциометрии

\begin{tabular}{l|c|c}
\multirow{2}{*}{ Параметр } & \multicolumn{2}{|c}{ Растворы } \\
\cline { 2 - 3 } & Раствор 1 & Раствор 2 \\
\hline$S_{\mathrm{oc}} \cdot 10^{4}, \mathrm{M}^{2}$ & 1,56 & 1,25 \\
\hline$k$ & 3,32 & 2,65
\end{tabular}

Значения $S_{\text {ос }}$ и $k$, измеренные при больших токах, представлены в табл. 2 . Полученные результаты указывают на развитие поверхности в процессе роста осадка меди. Однако зависи-

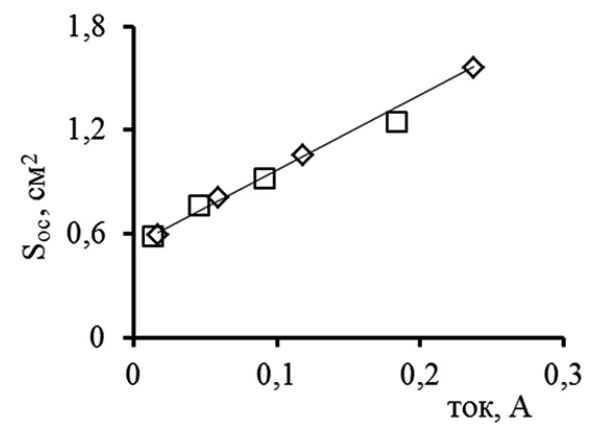

Рис. 3. Влияние тока на площадь поверхности дисперсного осадка меди, измеренную методом хронопотенциометрии. Осадки меди получены при $\mathrm{K}_{\mathrm{u}}=6$ из раствора $1(\diamond)$ и раствора $2(\square)$ мость результатов от величины тока при проведении измерений свидетельствует о невозможности измерения всей поверхности электрода с рыхлым осадком с помощью метода хронопотенциометрии.

2. Определение площади поверхности электрода с дисперсным осадком методом импедансной спектроскопии

Сравнение экспериментальных и расчетных спектров импеданса (рис. 4) свидетельствует о хорошей аппроксимации.

Результаты расчета величины площади поверхности по уравнениям (3), (4) представлены в табл. 3. Площадь дисперсного осадка, измеренная методом импеданса, в десятки раз превышает значения, полученные методом хронопотенциометрии (табл. 2).

С практической точки зрения большое значение имеет такая характеристика порошка, как удельная поверхность $S_{\text {уд }}=S_{\text {ос }} / m_{\text {ос }}$

Массу осадка определяли по закону Фарадея:

$$
m_{\mathrm{oc}}=\frac{A_{\mathrm{Cu}}}{z F} I \cdot t \cdot B m_{\mathrm{Cu}},
$$

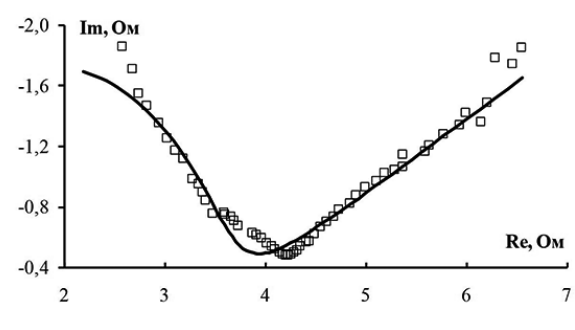

Рис. 4. Спектр импеданса осадка меди, полученного в растворе 1 .

Маркеры - экспериментальные данные, линия - аппроксимация по принятой эквивалентной схеме 
где $A_{\mathrm{Cu}}$ - атомная масса меди, $t$ - время электролиза, $I$ - ток, $B m_{\mathrm{Cu}}$ - выход по току меди.

Значения площади поверхности дисперсных осадков меди, измеренных методом импедансной спектроскопии

\begin{tabular}{l|c|c}
\multirow{2}{*}{ Параметр } & \multicolumn{2}{|c}{ Растворы } \\
\cline { 2 - 3 } & Раствор 1 & Раствор 2 \\
\hline$S_{\text {ос }} \cdot 10^{4}, \mathrm{M}^{2}$ & 20,825 & 6,348 \\
\hline$k$ & 44,214 & 13,478 \\
\hline $\mathrm{BT}$ & 0,78 & 0,23 \\
\hline$m \cdot 10^{4}, \Gamma$ & 2,73 & 0,62 \\
\hline$S_{\text {уд }}, \mathrm{M}^{2} / \Gamma$ & 5,921 & 2,337
\end{tabular}

При получении дисперсного осадка меди на электроде одновременно протекают реакции восстановления металла и водорода. По объему выделившегося в процессе электролиза газа определяли выход по току водорода, а затем рассчитывали выход по току меди:

$$
B m_{\mathrm{Cu}}=1-\frac{V_{\text {н.у. }}^{H_{2}} \cdot F}{\vartheta_{\Gamma} \cdot I \cdot t},
$$

где $V_{\text {н.у. }}^{\mathrm{H}_{2}}$ - объем водорода, приведенный к нормальным условиям $\vartheta_{\Gamma}$ - молярный объем газа.

Проведенные исследования показали, что при использовании раствора, содержащего серную кислоту, формируются дисперсные осадки меди с высокой удельной поверхностью (табл. 3). При электроосаждении из раствора с сульфатом натрия образуются менее разветвленные частицы, о чем свидетельствует существенно меньшая площадь поверхности осадка и низкая удельная поверхность.

На основании полученных результатов можно сделать вывод: метод импедансной спектроскопии может быть использован для измерения in situ площади поверхности дисперсных осадков меди.

\section{References}

1. Pomosov A. V., Krymakova E. E. Predicting the Properties of Electrolytic Copper Powder, Poroshk. Metall. 1976;6:1-4.

2. Ostanina T. N., Rudoy V. M., Nikitin V. S., Darintseva A. B., Zalesova O. L., Porotnikova N. M. Russian Journal of non-ferrous metals. 2014;3:15-20.

3. Vetter K. J. Electrochemical Kinetics, Theoretical and Experimental Aspects, Academic Press. New York, 1967.

4. Jurczakowski R., Hitz C., Lasia A. Impedance of porous Au based electrodes. Journal of Electroanalytical Chemistry. 2004;572:355-366.

Cite this article as (как цитировать эту статью):

Dolmatova E. A., Patrushev A. V., Ostanina T. N. Measurement of the specific surface area of loose copper deposit electrochemical methods. Chimica Techno Acta. 2016;3(2):147-155. DOI: 10.15826/chimtech.2016.3.2.011. 